\title{
The Influence of Health Facilities Information System Application in The Business Process of Clinic Bunga Melati
}

\author{
Geby Firdana Puspa ${ }^{1}$ and Raden Venantius Hari Ginardi ${ }^{2}$ \\ ${ }^{1}$ Department of Technology Management, Institut Teknologi Sepuluh Nopember, Surabaya \\ ${ }^{2}$ Department of Information Technology, Institut Teknologi Sepuluh Nopember, Surabaya \\ e-mail: hari@its.ac.id
}

\begin{abstract}
In this competitive business era, Klinik Bunga Melati (KBM) has changed its business and management strategies 3 times in the last 2 years with the aim of adjusting internal and external conditions in the health sector and make KBM superior to other competitors. KBM expects the development of technology that can be applied efficiently and integrated between KBM internally. In 2018, KBM teamed up with the Badan Penyelenggara Jaminan Sosial (BPJS) Kesehatan. In this regard, BPJS provides a Health Facilities Information System (HFIS) with the aim of making it easier for health units to make claims. But the leader of the KBM considers HFIS not suitable to be implemented in the KBM Welirang Branch. The KBM Welirang Branch staff must do $2 x$ recapitulation of patient medical records every day. There are quite a lot of variables in HFIS besides self-data, staff must also write data related to diagnosis, details of drugs used, drug costs, and doctor's fees. Based on the KBM leaders interview, this is considered to be very time-consuming and costly because HR has to work $2 x$ more and patients need more time to get action. HOT-Fit method is considered suitable for this research because this model can provide an explanation and provide an evaluation of the application a system in the field of health services from human factors (human), technology (technology), organization (organization) and net benefits. The output of this research is an analysis of aspects that need to be improved and the match rate of HFIS implementation in the KBM Welirang.
\end{abstract}

Keywords-Hot-Fit Model, Health Facilities Information System, Klinik Bunga Melati.

\section{I.INTRODUCTION}

In this competitive business era, it is hoped that all forms of business will be able to keep up with technological developments, including business in healthcare. As stated in the forbest, it is known that the healthcare service business helps develop the economy of developing countries by $10 \%$ and is the largest growing business in the world. Bunga Melati Clinic (KBM) has developed into 6 clinical branches in Malang, East Java since 2007 with quality human resources and facilities and strategic location that makes it easy for patients to seek treatment. KBM has different facilities and services in each of its clinics. The KBM Center is located on J1. Attorney General Suprapto, for the main clinic located on J1. Pandjaitan, for the partnership clinic of Siekes Melati Kostrad, located on Jl. Raya Malang Surabaya, a specialist clinic located on J1. Cakra Guna, the Rahmat seat partnership clinic is located on Jl. Tirto Mulyo, and KBM have just built a new specialist clinic on Jl. Welirang.
KBM has changed its business and management strategy 3 times in the last 2 years with the aim of adjusting internal and external conditions in the health sector and to make KBM superior to other competitors. Related to current business developments, KBM expects technological developments that can be applied efficiently and integrated between KBM internally. However, KBM found obstacles in the Management Information System (SIM) which is the main priority that is being sought for a solution this year, especially in the KBM Welirang Branch.

In connection with the development of the health unit, Indonesia also has a program from the government which we know as the Health Insurance Administering Agency (BPJS). Since 2014, BPJS has officially operated until now. In an effort to improve the quality of services that are better for patients and for health facilities, BPJS Health develops an Information Technology based system related to the increasing number of Indonesians using BPJS services. The BPJS Health information system is referred to as the Health Facilites Information System (HFIS). Each patient will be represented in alphanumeric code. BPJS Health seeks to socialize this HFIS to all hospitals, clinics, and health centers in Indonesia with the aim of making it easier for health units to make claims. But the problem now is that not all health units consider HFIS to facilitate the work of staff including KBM Welirang Branch.

For now, KBM Welirang Branch uses a manual system by optimizing Microsoft Excel for the data collection process of patients either independent patients or BPJS Health patients. KBM Welirang Branch staff must do a $2 \mathrm{x}$ recapitulation of patient medical records every day. First of all, KBM Welirang Branch staff manually input internal data per day for independent patients and BPJS Health patients. After that, KBM Welirang Branch staff input BPJS Health patient data into HFIS to get the Reference Number, then the Reference Number is used to get the Participant Eligibility Letter (SEP) where the SEP is used by the KBM Welirang Branch to get the V-claim from BPJS Health. There are quite a lot of variables in HFIS besides self-data, staff must also write data related to diagnosis, details of drugs used, drug costs, to doctor's fees. Based on KBM CEO interview data, this is certainly very time-consuming and costly because HR has to work $2 \mathrm{x}$ more and patients need more time to get action. The CEO of KBM thinks that HFIS is not suitable with the business and environmental conditions in KBM Welirang 
The $6^{\text {th }}$ International Seminar on Science and Technology (ISST) 2020

July $25^{\text {th }} 2020$, Institut Teknologi Sepuluh Nopember, Surabaya, Indonesia

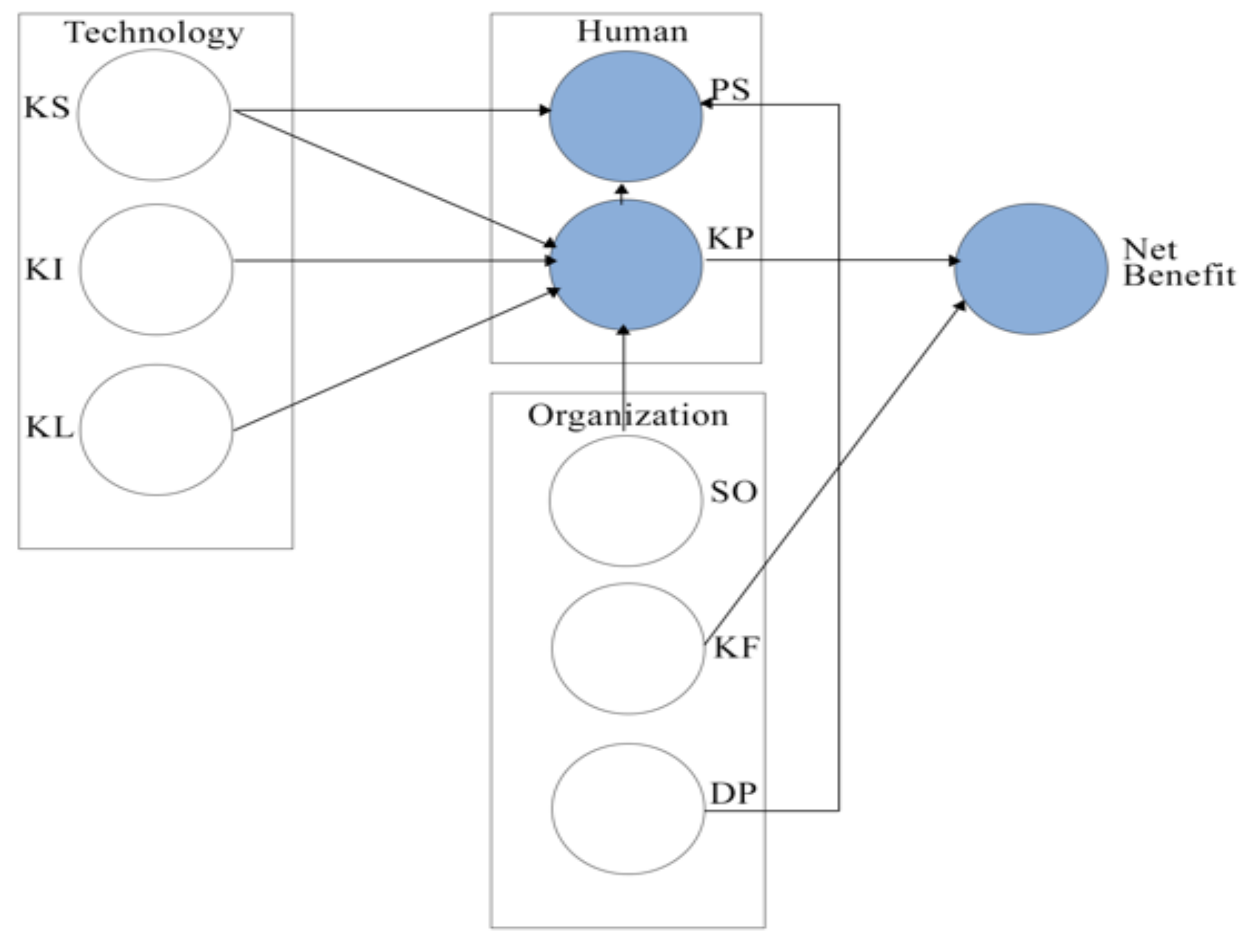

Figure 1. Inner Model.

Branch.

Based on the background above, it is necessary to do an analysis of the successful implementation of the HFIS information system at the Bunga Melati Clinic in the Welirang Branch using the Human Organization Technology (HOT) Fit method. Therefore, this study will measure the suitability of the application of the HFIS information system at the Bunga Melati Clinic in the Welirang Branch with the Hot-Fit method. Based on a number of previous studies, the HOT-Fit Model can be applied to the research title "The Influence of the Implementation of the Health Facilities Information System (HFIS) in the Business Process of Welirang Branch Melati Clinic" because Yusof (2006) argues that this evaluation model clarifies three important and fundamental components that are affect the successful adoption of information systems where the three components are mutually sustainable. HOT-Fit is considered suitable for this research because this model can provide an explanation and provide an evaluation of the application of a system in the field of health services from human factors, technology, organization and net benefit.The results of this study are in the form of an analysis of the suitability of the HFIS information system on KBM from human factors, organizational factors, and technological factors. In addition, the provision of recommendations will be given as a support for the system development plan in the KBM.

\section{METHODS}

Quantitative research methods are a method used to answer research problems related to data in the form of numbers and statistical programs [1]. This research uses descriptive quantitative research methods by conducting surveys and collecting primary data through interviews with guidance on distributing questionnaires to users of information systems as respondents. In this study, the object and material of the research are the users of the Health Facilites Information System of the Badan Penyelenggara Jaminan Sosial (BPJS) Kesehatan at the Bunga Melati Clinic (KBM) Welirang Branch. The making of the questionnaire is based on the HOT-Fit Model method, where the identification of research variables is carried out through the literature study process in previous research as the basis for the preliminary survey to obtain relevant variables to be modeled and analyzed. The following will identify the variables needed in research. The variables in this study consisted of two types namely endogenous variables and exogenous variables.

From Figure 1 and Table 1 is determined that there are three endogenous variables namely System Use (PS), User Satisfaction (KP), and Net Benefit (Benefits) which are influenced by six exogenous variables namely System Quality (KS), Information Quality (KI), Service Quality ( KL), Organizational Structure (SO), Facility Conditions (KF), and Leadership Support (DP) [2]. This study uses the Hot-Fit model developed by Yusof et al, with several modifications to assess the successful implementation of the HFIS information system. One way is to eliminate organizational environment variables (organization environment). Because these variables are considered too broad so researchers replace the organizational environment variables with facilitating conditions and top management support [2]. 
The $6^{\text {th }}$ International Seminar on Science and Technology (ISST) 2020

July $25^{\text {th }} 2020$, Institut Teknologi Sepuluh Nopember, Surabaya, Indonesia

Table 1.

Indicator Variable

\begin{tabular}{|c|c|c|}
\hline Variabel Laten & Indikator Variabel & Kode \\
\hline \multirow{4}{*}{ System Quality } & Users can understand the workflw of the HFIS & KS1 \\
\hline & Data confidentially & KS2 \\
\hline & HFIS can be accessed both in dekstop and mobile & KS3 \\
\hline & HFIS rarely experiences errors & KS4 \\
\hline \multirow{4}{*}{ Information Quality } & Output matches with input & KI1 \\
\hline & Output matches with the real data & KI2 \\
\hline & Output is precise and accurte & KI3 \\
\hline & Output is complete and detailed & KI4 \\
\hline \multirow{4}{*}{ Service Quality } & Output is easy to read & KI5 \\
\hline & Manual book & KL1 \\
\hline & Fast and responsive service from HFIS server & KL2 \\
\hline & HFIS can not be accessed outside KBM & KL3 \\
\hline & Simplifies the process of finding data & PS1 \\
\hline & Help the user's daily work & PS2 \\
\hline & Help in decision making & PS3 \\
\hline \multirow{3}{*}{ System Use } & Users have expertise in using HFIS & PS4 \\
\hline & User's work depends on HFIS & PS5 \\
\hline & Users are satisfied with the use of HFIS & KP1 \\
\hline \multirow{3}{*}{ User Satisfication } & Users are satisfied with the user interface of HFIS & KP2 \\
\hline & Easy to use & KP3 \\
\hline & No need to develop \& improve & KP4 \\
\hline \multirow{3}{*}{ Organization Structure } & $\begin{array}{l}\text { HFIS is applied as a health service improvement strategy in collaboration with the BPJS } \\
\text { Kesehatan }\end{array}$ & SO1 \\
\hline & HFIS can help coordinate between BPJS Kesehatan and KBM & $\mathrm{SO} 2$ \\
\hline & Management provides infrasturcture to support implementation of HFIS & $\mathrm{SO} 3$ \\
\hline \multirow{3}{*}{ Facilitating Condition } & KBM provides software that supports the use of HFIS & KF1 \\
\hline & BPJS provides hardware that supports the use of HFIS & KF2 \\
\hline & BPJS provides the officer in charge and provides assistance in the event of problem with HFIS & KF3 \\
\hline \multirow{3}{*}{ Top Management } & Leader considers HFIS is efficient for KBM & DP1 \\
\hline & Leader considers HFIS is improving the performance of KBM Staff & DP2 \\
\hline & HFIS lightens daily work tasks & M1 \\
\hline \multirow{4}{*}{ Net Benefit } & HFIS improves work efficiency & M2 \\
\hline & HFIS helps achieve goals effectively & M3 \\
\hline & HFIS can improve communication between BPJS Kesehatan and KBM & M4 \\
\hline & HFIS can support vision and mission of the organization & M5 \\
\hline
\end{tabular}

\section{III.RESULTS AND DISCUSSION}

\section{A.Variation Test}

In statistics, the standard deviation is a measure used to measure the amount of variation or the distribution of a number of data values. The lower the standard deviation, the closer it is to the average. Meanwhile, if the higher the standard deviation, the wider the variation of the data range.

After knowing the mean per indicator in the HFIS questionnaire research data in Table 2 , then proceed to the validity test stage. Standard deviations can be calculated with the following formula:

$$
\begin{aligned}
& S=\sqrt{\frac{\sum y^{2}-\frac{\left(\sum y\right)^{2}}{n}}{n-1}} \\
& =\sqrt{\frac{526,076-\frac{131,570^{2}}{33}}{33-1}}=\sqrt{\frac{526,076-524,57}{32}}=\sqrt{\frac{1,511}{32}} \\
& =\sqrt{0,05}=0,217
\end{aligned}
$$

The standard deviation result is 0.217 and includes a low value. It can be said that the range of questionnaire data variants is not too far apart.

\section{B. Hypotesis Testing}

From the Table 3 it can be seen that the hypothesis is rejected or accepted by looking at the value of $t$ statistics compared to $\mathrm{t}$ table, in hypothesis testing the significance level is $95 \%$. the value of $t$ table with a significance level of $95 \%$ is 1.796 . Based on the results of the t-test, then the hypothesis test can be determined in this study:

1. H1 : System quality (KS) has a significant positive effect on system use (PS).The t-statistic result KS> PS has a calculated value of 2.132. T-count value is greater than ttable, then $\mathrm{H} 1$ is accepted or there is a positive effect of KS on PS.

2. H2 : System quality (KS) has a significant positive effect on user satisfaction (KP). The t-statistic result KS> KP has a calculated value of 2.132. T-count value is greater than t-table, then $\mathrm{H} 2$ is accepted or there is a positive effect of KS on the KP.

3. H3 : System quality (KS) has a significant positive effect on organizational structure (SO). The t-statistic result $\mathrm{KS}>\mathrm{SO}$ has a calculated value of 2.353. The value of $\mathrm{t}-$ count is greater than t-table, then $\mathrm{H} 3$ is accepted or there is a positive effect of $\mathrm{KS}$ on $\mathrm{SO}$

4. $\mathrm{H} 4$ : Information quality (KI) has a significant positive effect on system use (PS). The results of t-statistic KI> PS have a calculated value of 1.859 . The value of $t$-count is greater than t-table, then $\mathrm{H} 4$ is accepted or there is a positive effect of IC on PS 
The $6^{\text {th }}$ International Seminar on Science and Technology (ISST) 2020

July $25^{\text {th }} 2020$, Institut Teknologi Sepuluh Nopember, Surabaya, Indonesia

Table 2.

Indicator Data Table

\begin{tabular}{|c|c|c|}
\hline Indikator & $\mathrm{Y}$ & $\mathrm{Y}^{2}$ \\
\hline KS1 & 3,910 & 15,288 \\
\hline KS2 & 4,540 & 20,612 \\
\hline KS3 & 4,180 & 17,472 \\
\hline KS4 & 3,450 & 11,903 \\
\hline KI1 & 4,270 & 18,233 \\
\hline $\mathrm{KI} 2$ & 4,180 & 17,472 \\
\hline $\mathrm{KI} 3$ & 4,270 & 18,233 \\
\hline KI4 & 4,270 & 18,233 \\
\hline KI5 & 3,900 & 15,210 \\
\hline KL1 & 3,810 & 14,516 \\
\hline KL2 & 3,730 & 13,913 \\
\hline KL3 & 3,550 & 12,603 \\
\hline PS1 & 3,910 & 15,288 \\
\hline PS2 & 3,910 & 15,288 \\
\hline PS3 & 4,270 & 18,233 \\
\hline PS4 & 3,910 & 15,288 \\
\hline PS5 & 3,820 & 14,592 \\
\hline KP1 & 4,090 & 16,728 \\
\hline KP2 & 3,820 & 14,592 \\
\hline KP3 & 4,000 & 16,000 \\
\hline KP4 & 3,820 & 14,592 \\
\hline SO1 & 4,000 & 16,000 \\
\hline $\mathrm{SO} 2$ & 4,090 & 16,728 \\
\hline SO3 & 4,090 & 16,728 \\
\hline KF1 & 4,090 & 16,728 \\
\hline KF2 & 4,090 & 16,728 \\
\hline KF3 & 4,000 & 16,000 \\
\hline DP1 & 4,090 & 16,728 \\
\hline M1 & 3,810 & 14,516 \\
\hline M2 & 3,900 & 15,210 \\
\hline M3 & 3,900 & 15,210 \\
\hline M4 & 3,900 & 15,210 \\
\hline M5 & 4,000 & 16,000 \\
\hline Total & 131,570 & 526,076 \\
\hline
\end{tabular}

5. H5 : Information quality (KI) has a significant positive effect on user satisfaction (KP). T-statistic results $\mathrm{KI}>\mathrm{KP}$ has a $t$-value of 1.895. The value of $t$-count is greater than $\mathrm{t}$-table, then $\mathrm{H} 5$ is accepted or there is a positive influence of IC on KP.

6. H6 : Information quality (KI) has a significant positive effect on organizational structure (SO). The result of tstatistic KI> SO has a calculated value of 2,015. T-count value is greater than t-table, then $\mathrm{H} 6$ is accepted or there is a positive influence of $\mathrm{KI}$ on $\mathrm{SO}$.

7. H7 : Quality of service (KL) has a significant positive effect on system use (PS). The t-statistic result KL> PS has a calculated value of 2,015. T-count value is greater than $\mathrm{t}$-table, then $\mathrm{H} 7$ is accepted or there is a positive influence of KL on PS

8. H8 : Quality of service (KL) has a significant positive effect on user satisfaction (KP). T-statistic results KL> $\mathrm{KP}$ has a calculated value of 2.132. The value of $t$-count is greater than t-table, then $\mathrm{H} 8$ is accepted or there is a positive influence of KL on the KP.

9. H9 : Service quality (KL) has a significant positive effect on organizational structure $(\mathrm{SO})$. The t-statistic result $\mathrm{KL}>\mathrm{SO}$ has a calculated value of 2.353 . The value of $\mathrm{t}$ count is greater than t-table, then H9 is accepted or there is a positive influence of $\mathrm{KL}$ on $\mathrm{SO}$.

10. H10 : Organizational structure (SO) has a significant positive effect on user satisfaction (KP). The result of tstatistic $\mathrm{SO}>\mathrm{KP}$ has a t-value of 2.132. The value of $\mathrm{t}$ count is greater than t-table, then $\mathrm{H} 10$ is accepted or there is a positive influence of SO on KP.
Table 3.

T-Test Results

\begin{tabular}{ccc}
\hline \hline No & Hypothesis & Nilai \\
\hline 1 & KS $>$ PS & 2,131846786 \\
2 & KS $>$ KP & 2,131846786 \\
3 & KS $>$ SO & 2,353363435 \\
4 & KI $>$ PS & 1,859548038 \\
5 & KI $>$ KP & 1,894578605 \\
6 & KI $>$ SO & 2,015048373 \\
7 & KL $>$ PS & 2,015048373 \\
8 & KL $>$ KP & 2,131846786 \\
9 & KL $>$ SO & 2,353363435 \\
10 & SO $>$ KP & 2,131846786 \\
11 & KP $>$ PS & 1,894578605 \\
12 & DP $>$ PS & 2,015048373 \\
13 & KP $>$ M & 2,131846786 \\
14 & KF $>$ M & 2,015048373 \\
\hline \hline
\end{tabular}

11. H11 : User satisfaction (KP) has a significant positive effect on system usage (PS). The t-statistic KP> PS has a calculated value of 1.895 . T-count value is greater than $\mathrm{t}$ table, then $\mathrm{H} 11$ is accepted or there is a positive influence of KP on PS.

12. H12 : Leadership support (DP) has a significant positive effect on the use of the system (PS). The result of tstatistic DP> PS has a calculated value of 2,015. T-count value is greater than t-table, then $\mathrm{H} 12$ is accepted or there is a positive influence of DP on PS.

13. H13 : User satisfaction (KP) has a significant positive effect on benefits (M). The t-statistic KP> M has a calculated value of 2.132. T-count value is greater than $\mathrm{t}$ table, then $\mathrm{H} 13$ is accepted or there is a positive influence of KP on M.

14. H14 : Facility conditions (KF) have a significant positive effect on benefits (M). The result of $t$-statistic KF> M has a calculated value of 2,015. T-count value is greater than t-table, then H14 is accepted or there is a positive influence of KP on M.

\section{CONCLUSION}

With the HOT-Fit Model approach consisting of System Quality, Information Quality, Service Quality, System Usage, User Satisfaction, Organizational Structure, Facility Conditions, Leadership Support, and Benefits, it can be seen the success rate of HFIS system implementation at Bunga Melati Malang Branch, Welirang Branch . Based on the results of the study, it can be concluded as follows: (1)Human factors on the use of the HFIS system at the KBM Welirang Branch can be seen from several variables, including: (a)The quality of the HFIS is quite good, this can be shown from the percentage value of each indicator on the System Use (PS) variable showing a positive response, but it still needs to be developed on all indicators because 27.27 of the respondents' answers are Disagreeing; (b) The results of the questionnaire on the use of the system by KBM staff showed that KBM staff were more receptive to the existence of HFIS automation because it was in accordance with staff needs; (c) The User Satisfaction Variable (KP) has given a positive response even though the Hi-Tech System indicator (KP4) looks $45.45 \%$ in the Disagreeing column. KP4 is related to the needs of 
The $6^{\text {th }}$ International Seminar on Science and Technology (ISST) 2020

July $25^{\text {th }} 2020$, Institut Teknologi Sepuluh Nopember, Surabaya, Indonesia

developing the HFIS system; (d) H13 shows user satisfaction (KP) significantly positive effect on benefits (M); (2) Organizational factors (organization) on the use of the HFIS system at the KBM Welirang Branch can be seen from several variables, including: (a) The Organizational System Variable shows a positive response mainly from the Coordination and Infrastructure indicators, although an increase in the Service Strategy indicator is needed; (b) Provision of Technicians (KF3) still needs to be improved, bearing in mind the Facility Condition indicator also influences the Benefits of using the HFIS system in accordance with $\mathrm{H} 14$; (c) The condition of the facility supports the benefits of HFIS for the Bunga Melati Clinic in the Welirang Branch; (d) Leadership Support gave good results on the Use of the HFIS System at Malang Melati Bunga Clinic, Welirang Branch; (3) Technological factors (technology) on the use of the HFIS system in KBM Welirang Branch can be seen from several variables, including: (a) System Quality Variable (KS) can be expressed quite well especially on the Data Security indicator (KS2). However, for other indicators such as the Easy to Understand indicator
(KS1), the Ease of Access indicator (KS3) still needs improvement, especially in the System Functional Indicator (KS4) which has a high enough percentage in the Disagree column which is 54.54\%; (b) The Information Quality Variable (KI) in the HFIS system is arguably good, this can be seen from the percentage value of each indicator reaching $90 \%$ showing positive results. The quality of information that is already good must be maintained but also needs to be improved in the Easy to Read indicator (KI5); (c) The Service Quality Variable (KL) can be expressed quite well but there is a need for development of the Manual Book Availability (KL1) indicator, the Responsive Service indicator (KL2), and the System Access indicator (KL3). Considering TOS influences User Satisfaction and Organizational Systems.

\section{REFERENCES}

[1] Wahidmurni, M.Pd, Dr., (2019) Pemapatan Metode Penelitian Kuantitatif, UNI Maulana Malik Ibrahim Malang

[2] Abda'u, Prih Diantono, (2018), Evaluasi Penerapan SIMRS Menggunakan Metode Hot-Fit Di RSUD Dr. Soedirman Kebumen, Jurnal Ilmiah Penelitian dan Penerapan Teknologi Sistem Informasi, UNP Kediri. 